\title{
TOURISTS’ PERCEPTIONS OF LANGKAWI ISLAND AS A WORLD TOURISM DESTINATION
}

\author{
Nurhazani MOHD SHARIFF* \\ Universiti Utara Malaysia, School of Tourism, Hospitality \& Event Management, COLGIS, 06010, Sintok, Kedah, Malaysia, e-mail: hazani@uum.edu.my
}

Azlan ZAINOL ABIDIN

Universiti Utara Malaysia, Tunku Puteri Intan Safinaz School, COB, 06010, Sintok, Kedah, Malaysia, e-mail: azlan@uum.edu.my

\begin{abstract}
Citation: Mohd Shariff, N., \& Zainol Abidin, A. (2020). TOURISTS' PERCEPTIONS OF LANGKAWI ISLAND AS A WORLD TOURISM DESTINATION. GeoJournal of Tourism and Geosites, 32(4), 1264-1269. https://doi.org/10.30892/gtg.32411-567
\end{abstract}

\begin{abstract}
Tourists' perceptions of a destination play essential roles in determining the purpose behind the behaviour of visiting the place. Hence, it enables the tourism planners to comprehensively predict tourists' actions. Several studies have debated the importance of researching the perceptions of tourists on destination to develop effective strategic marketing planning. In line with this issue, the main purpose of the study is to investigate tourists' perceptions of Langkawi Island as a world tourism destination. Today, Langkawi Island has increasingly active in promoting itself to be eminently known as a world tourism destination. A survey was conducted involving 677 tourists including both local and international tourists visiting the island. Interestingly, the findings indicate that most of the tourists are first time visitors and have stayed in Langkawi between $3-7$ days, travelling in a group of less than 5 and have made their own travel arrangement. Among the purposes of visiting the island are to experience the natural resources and historical places of the island. In fact, the majority of tourists want to experience the interesting life in Langkawi as more as possible. Generally, the findings reveal that tourists have perceived Langkawi Island positively as a world tourism destination. The study eventually would assist the stakeholders particularly the policy makers and tourism marketers to have better and comprehensive information regarding tourists' perceptions of the island. Additionally, the findings would also assist the tou rism planners to actively promote the beauty and natural resources of Langkawi Island and potray it as a world tourism destination.
\end{abstract}

Key words: Tourist, perception, tourism destination, Langkawi Island

$$
* \quad * \quad * \quad * *
$$

\section{BACKGROUND OF THE STUDY}

Langkawi Island is in the northern region of West Malaysia, located at the north of the Straits of Malacca, approximately $30 \mathrm{~km}$ from Kuala Perlis; $51.5 \mathrm{~km}$ from Kuala Kedah; and $109 \mathrm{~km}$ from Penang. Today, tourism has become a well-known industry in the island which significantly contributed towards the enhancement of local communities particularly in the sense of providing greater economic benefits for the country. In line with this development, Langkawi Island is increasingly active on promoting itself to be emi nently known as world-class tourist destination similarly to Phuket, Thailand and Bali, Indonesia. Langkawi Island is also known as a popular destination for famous sports events for instance Langkawi International Maritime and Aerospace (LIMA), Le Tour de Langkawi, Langkawi International Regatta, Langkawi Ironman Triathlon, and Langkawi International Dialogues (LID).

The development of Langkawi Island as a tourism destination has begun with the conferring on the Duty Free Zone status in 1987, followed by the establishment of the Langkawi Development Authority (LADA) in 1990 and has been one of the agendas in the Sixth Malaysia Plan (1991 - 1995). These acknowledgements have led to a more systematic development of the island and transformed Langkawi into the modern tourist island destination. The recognition of Langkawi Island by UNESCO as Malaysia's first Global Geopark in June 2007 eventually has brought in more visitors, researchers and nature enthusiasts. Langkawi Island still remains as one of the top tourist destinations for Malaysia even though the number dropped slightly in 2005 to 1.8 million due to the post-tsunami impact (LADA, 2016; Tourism Malaysia, 2016). Further, the government, private sectors and local communities have also experienced a considerable amount of economic development as a result of the booming tourism industry in Langkawi Island (Anand and Sen, 2000).

As reported by LADA (2015), Langkawi Island has received about RM 2.6 billion revenue from the approximately 3 million recorded tourist arrivals in 2012. In line with this achievement, the government has taken prompt action by proposing a Blueprint Langkawi to make Langkawi Island listed as 10 highest islands visited by tourists as well as to make Langkawi as a luxury tourist destination by the year 2015 . Added to this, the target in economics is to double tourism in Langkawi Gross National Income (GNI) of RM 0.8 billion in 2010 to RM 1.9 billion in 2015. Further, recipients are also expected to double from RM 1.9 billion tourists in 2010 to RM 3.8 billion in 2015 through the launching of marketing campaign based on customer needs. The major purpose of this marketing is to enhance the itinerary of foreign countries to Langkawi and product marketing in the luxury market and high spending tourists. As for the year $2016,3.3$ million tourists arrivals in Langkawi Island was recorded, an increment of 8.1\% compared to 2015 (LADA, 2016). The year 2018 has shown a rapid growth of tourists' arrivals of 3.67 million with recorded revenue of RM 5.6 billion (LADA, 2019).

Even though there have been various studies on Langkawi Island as a tourism destination, studies on tourists' perceptions of visiting it as world tourism destination are still lacking. Hence, this study was conducted to investigate tourists' perceptions of Langkawi Island in order to promote it as a world tourism destination. It is important in the first place to understand tourists' perceptions of Langkawi as it plays a key role in planning activities more effectively by the tourism authority. The creation of perceived images will vary with regards to personal beliefs and demographic factors. According to Munien et al. (2019), examining visitor profiles, perceptions, preferences and experiences is important to improve planning and management of these destinations to ensure long-term sustainability. Hence, by investigating why people engage themselves in travelling will assist the Langkawi destination marketers and planners to gain insight into tourism development and marketing process. Moreover, the information may provide better explanation to authorities, marketers and service providers of Langkawi Island regarding tourists' behaviors and actions. Additionally, the findings on tourists' perceptions can be used by the local people to assist tourists in having an enjoyable and memorable time during their stay. The valuable information compiled would also assist the stakeholders to implement effective market segmentation and targeting Langkawi Island as a world tourism destination.

\footnotetext{
* Corresponding author
} 


\section{LITERATURE REVIEW}

Study on tourists' perception of a destination's image as a preferred choice for travel is crucial. Munien et al. (2019) examined tourists' profiles in Cape Town and found that tourist profiles such as gender, age and educational level play important roles to improve the planning and management of tourist destination. According to Law (1995), tourists' perception affects the formation of a destination image, and in return, the perception is affected by specifying the similarities and differences among the facilities, attractions, and service standards of several destinations. As noted in a study by Farsani et al. (2019), tourists like to discover new destinations thus it is vital to study their perceptions and satisfaction of a destination. Their study on mines as tourist attractions indicated that tourists would choose to stay at geo-accommodation and visiting underground as their geotours. Pantano et al. (2017) conducted a study regarding tourists' perceptions of a certain attraction using open data sources. The purpose was to form appropriate future travel propositions as well as the reliability of online reviews on formulating intentions. The study also contributed to the importance of understanding tourists' perceptions and created new challenges particularly to the tourism managers to make better predictions about the destination. Further, Athula Gnanapala (2015) surveyed tourists' perception and satisfaction of Sri Langka as tourism destination and found relationships among the psychological variables, such as motivation, attitude, perception, and satisfaction. The study concluded that tourists would make repeat visits and spread positive word of mouth publicity if that destination could identify and satisfy their needs and want. Hence, it is vital to study tourists' perceptions of a destination as it will lead to important developments and the growth of the tourism industry.

According to Augustyn and Ho (1998), destination marketing can be facilitated well with a better understanding of tourists' perceptions, needs and motives. Before a marketing program aimed at a specific market segment, tourism companies should understand the typical tourists' perceptions of that particular market. On the other hands, findings on tourists' perceptions can be used by the local people and employees of the tourism facilities to help assist tourists in having an enjoyable and memorable time during their stay. Baloglu and McCleary (1999) suggested that countries seeking to increase their tourism should consider the characteristics of their target markets and tailor their image development and positioning efforts to specific sociodemographic, perceptions and motivation segments. Study on tourists' perceptions is also considered important since tourists behavior may lead to their perceptions on the dest ination image. Since image of tourism destination depends on tourists' perceptions, several researchers have conducted an extensive studies to understand this phenomenon. Breitsohl and Garrod (2016) conducted an online survey involving 1350 tourists to understand their perceptions and emotions toward breach of ethics at a tourism destination. The study used cognitive appraisal theory and the findings indicated that tourists play major role in shaping hostile emotions toward tourism destination. They also noted that tourists' perceptions and word-of-mouth would likely lead to re-visit of the destination.

Further, Maghsoodi Tilaki et al. (2017) investigated the behavior of tourists visiting Penang Island, Malaysia and found that tourists' perceptions and expectations are vital in promoting the destination in the media sources. They concluded that examining the tourists' perceptions and behaviors would provide better understanding of the most influential factors in realizing tourists' satisfaction. They also highlighted in their study that destination image is also influenced by the tourists' experiences. Hence, the results of this study indicated a negative gap for perceived destination image and suggested that the tourists' expectations are greater than their real actual experiences in the destination. Previously, Ahmed (1991) conducted a research on tourism by focusing on the perceptions of tourists toward destination, in consideration of the fact that a traveller's perceptions can influence tourism marketing. Assael (1984) found that an image of a destination is established by a collection of perceptions regarding a product or service, which are obtained from different sources. Hence, it is important to study and investigate the tourists' perceptions of a destination to plan for effective marketing strategy.

Heung and Quf (2000) emphasized that it is critical to develop infrastructure, products and services to satisfy tourists' pre ferences for Hong Kong as a travel destination. Therefore, they studied the understanding of the preferences and travel related behavior of tourists and found that it is vital for tourism marketing in terms of market segmentation and the design of effective promotional campaign. In other studies, it was noted that the perception of a country or a specific destination is developed on an individual basis and the perceived expectations of tourists can be a factor in determining the effectiveness of destination branding. Chheang (2011) emphasized that tourist's perception of Angkor is positive and their experiences are beyond expectations. It was also found by Bertan and Altintaş (2013) in their study that to increase the number of visitors coming to the Pamukkale region, the great value should be placed on the perceptions of visitors. Wang et al. (2016) also agreed that assessing tourists' perceptions is in line with examining their expectations of the destination which eventually lead in achieving standard levels in the quality of service to ensure satisfaction. Hence, tourist expectation has been defined as a preconceived perception of travel outcome.

Interestingly, studies also found that tourists play important role not just in terms of their perceptions and expectations, but also their motivations. For instance, a study on cultural and heritage sites in Kwazulu Natal, South Africa highlighted that tourists would visit the place due to several push factors such as desire for escape, relaxation and exploration of cultural heritage sites whilst unique cultural heritage sites, knowledge of Zulu Kingdom and good place for family are among the pull factors motivating tourists to visit the place (Ndlovu, 2015). Pantouvakis and Patsiouras (2016) in their study found that several factors motivated tourists to visit tourism destination such as the customs procedures, the cultural and historical attractions, the low crime rate, the constant political environment, the stability of currency and exchange rate, the availability of night life activities and of recreation facilities, the overall value and level of cost and finally the availability of hotels. Additionally, the study noted that the nationality of the tourist would also affect their choice of a destination. These motivational push and pull factors are significantly in line with tourists' purposes of visiting a tourism destination.

\section{METHODOLOGY}

In order to attain the stated research objective, the study was based on a descriptive research approach where specific information requirements and a quantitative methodology was used. Basically, the study was an exploratory study to understand and examine tourists' perceptions of Langkawi Island as a world tourism destination. The primary data was acquired through questionnaire distribution to 1000 tourists visiting Langkawi in three months time of peak seasons; March, June and December 2016. Most tourists were targeted at famous spot in Langkawi such as Pantai Cenang, Kuah Jetty and Airport. Questionnaire was chosen because of its ease of use and it provides the most possible alternative for measuring unobservable constructs such as attitudes, values and personalities. Further, according to Sekaran and Bougie (2010), survey questionnaire is an efficient data collection mechanism to ensure relevancy and consistency of information gathered as the responses are objective, standardised and comparable.

The questionnaire was divided into three sections namely Section A, B and C. Section A consisted of 11 items on tourists' demographic profiles such as gender, age, marital status, country of origin, educational level, profession, amount spending in Langkawi Island, number of trips to Langkawi Island, number of days in Langkawi Island during the visit, number of persons travelling together 
and arrangements to Langkawi Island. Section B asking the tourists' purposes of visiting Langkawi Island. Further, Section C asking the tourists their perceptions of Langkawi Island and also their perceptions regarding values and portrait of Langkawi as a world tourism destination. This section was measured with five Likert scale ranged from totally disagree to totally agree.

The study further used the Statistical Program for Social Science (SPSS) with descriptive and inferential analysis to identify patterns and general trends in the dataset of this study. Descriptive analysis refers to the transformation of raw data into a form that make them easier to understand and interpret (Zikmund et al., 2010). Hence, descriptive analyses such as frequency counts, percentages and cumulative percentages were employed in this study. A univariate and bivariate analysis was also performed on all variables; displaying means, standard deviations, frequencies, percentages, cumulative frequencies and cumulative percentages.

\section{FINDINGS}

\section{Tourists' Profiles}

A total of 677 tourists respond to the questionnaire representing a $67.7 \%$ response rate. Table 1 indicates the findings regarding tourists' profiles. It is noted that the majority of the tourists are female (51.0\%) and the remaining are male (49.0\%). As for the age distribution, the survey shows that most of them are between 18 - 34 years old $(83.8 \%)$, follows by 35 to 54 years old (12.3\%), and then tourists who are above 50 years old $(3.7 \%)$. Additionally, most of the tourists are also single (44.0\%) and married (44.0\%). The findings also highlight that majority of the tourist possessed a degree from university $(57.0 \%)$. Further, the profiles of tourists indicate that most of them are students $(31.0 \%)$, company employee $(23.0 \%)$ and also government servant (18.0\%). It can be seen that most tourists spent between RM3,000 RM4,999 (36.8\%) and only few spent between RM5,000 - RM6,999 (2.4\%).

The findings also highlight that the majority of the tourists are first time visitors to Langkawi (68.0\%). The survey shows that majority of the tourists stayed in Langkawi between $3-7$ days (51.0\%) and visited Langkawi in a group of less than five persons (77.4\%). Additionally, majority made their own arrangement for the trip (52.0\%) whilst some used overseas travel agent (25.8\%), few used local travel agent to plan for their trip (12.3\%) and the remaining made arrangement through their friends or relatives (9.9\%). The findings also indicate that majority of the tourists are local tourists or Malaysians (39.0\%) which presented by tourists from outsides Langkawi, for instance, Kuala Lumpur, Melaka, Johor, Penang, Sabah and many more. This is then followed by tourists from China (13.0\%). Further, similar findings were noted for tourists who visited Langkawi from Australia, United Kingdom and other European countries (7.0\%).

Table 1. Tourists' Profiles

\begin{tabular}{|c|c|c|c|}
\hline Profile & Percentage & Profile & Percentage \\
\hline $\begin{array}{l}\text { Gender: } \\
\text { Male } \\
\text { Female }\end{array}$ & $\begin{array}{l}49.0 \\
51.0\end{array}$ & $\begin{array}{l}\text { Travel arrangement: } \\
\text { Overseas travel agent } \\
\text { Local travel agents } \\
\text { Friends/relatives } \\
\text { On your own }\end{array}$ & $\begin{array}{c}25.8 \\
12.3 \\
9.9 \\
52.0\end{array}$ \\
\hline $\begin{array}{l}\text { Age: } \\
18-34 \text { years old } \\
35-54 \text { years old } \\
\text { Above } 55 \text { years old } \\
\text { Missing value }\end{array}$ & $\begin{array}{l}83.8 \\
12.3 \\
3.7 \\
0.3\end{array}$ & $\begin{array}{l}\text { Professions: } \\
\text { Student } \\
\text { Government servant } \\
\text { Company employee } \\
\text { Self-employed } \\
\text { Retired } \\
\text { Unemployed } \\
\end{array}$ & $\begin{array}{l}31.0 \\
18.0 \\
23.0 \\
17.0 \\
3.0 \\
8.0\end{array}$ \\
\hline $\begin{array}{l}\text { Marital status: } \\
\text { Single } \\
\text { Married } \\
\text { In relation } \\
\text { Separate }\end{array}$ & $\begin{array}{c}44.0 \\
44.0 \\
12.0 \\
0.0\end{array}$ & $\begin{array}{l}\text { Number of persons travelled } \\
\text { together: } \\
\text { Less than } 5 \text { persons } \\
5-10 \text { persons } \\
\text { More than } 10 \text { persons }\end{array}$ & $\begin{array}{c}77.4 \\
18.0 \\
4.6\end{array}$ \\
\hline $\begin{array}{l}\text { Level of education: } \\
\text { High school certificate } \\
\text { College diploma } \\
\text { University degree } \\
\text { Masters/PhD } \\
\text { Did not finish high school }\end{array}$ & $\begin{array}{c}6.0 \\
28.0 \\
57.0 \\
9.0 \\
0.0\end{array}$ & $\begin{array}{l}\text { Amount spending in Langkawi: } \\
\text { Less than RM1000 } \\
\text { RM1000 - RM2999 } \\
\text { RM3000 - RM4999 } \\
\text { RM5000 - RM6999 } \\
\text { More than RM7000 }\end{array}$ & $\begin{array}{c}34.1 \\
26.6 \\
36.8 \\
2.4 \\
0.1 \\
\end{array}$ \\
\hline $\begin{array}{l}\text { Number of trips to Langkawi: } \\
\text { First time } \\
1-3 \text { times } \\
\text { More than } 3 \text { times }\end{array}$ & $\begin{array}{c}68.0 \\
24.0 \\
8.0\end{array}$ & $\begin{array}{l}\text { Country of origin: } \\
\text { Malaysia (local) } \\
\text { China } \\
\text { Australia } \\
\text { United Kingdom } \\
\text { Other European countries } \\
\text { Arab countries } \\
\text { Indonesia } \\
\text { Thailand } \\
\text { Other countries }\end{array}$ & $\begin{array}{c}39.0 \\
13.0 \\
7.0 \\
7.0 \\
7.0 \\
6.0 \\
5.0 \\
5.0 \\
11.0\end{array}$ \\
\hline $\begin{array}{l}\text { Number of days staying in } \\
\text { Langkawi: } \\
\text { Less than } 3 \text { days } \\
3-7 \text { days } \\
\text { More than } 7 \text { days }\end{array}$ & $\begin{array}{l}38.0 \\
51.0 \\
11.0\end{array}$ & & \\
\hline
\end{tabular}

\section{Tourists Purposes of Visiting Langkawi}

Figure 1 highlights 12 common purposes of tourists visiting Langkawi. The findings indicate that the majority of the tourists visited Langkawi to gain experience of the island as a tourism destination (79.2\%). Most of them also visited Langkawi for relaxing (64.5\%), visiting natural sites in Langkawi (55.7\%) and also visiting historical places and attractions in Langkawi (40.6\%). Besides these reasons, one of the main reasons visiting Langkawi is to visit the museums (35.3\%), few of the tourists also visited Langkawi for shopping (32.3\%). 
Only few tourists visited Langkawi for the purpose of attending cultural events (13.0\%), attending festival (11.4\%), visiting friends and relatives $(8.9 \%)$ and go to night club (4.3\%). Additionally, few indicates for other reasons $(0.9 \%)$ and fishing $(0.3 \%)$.

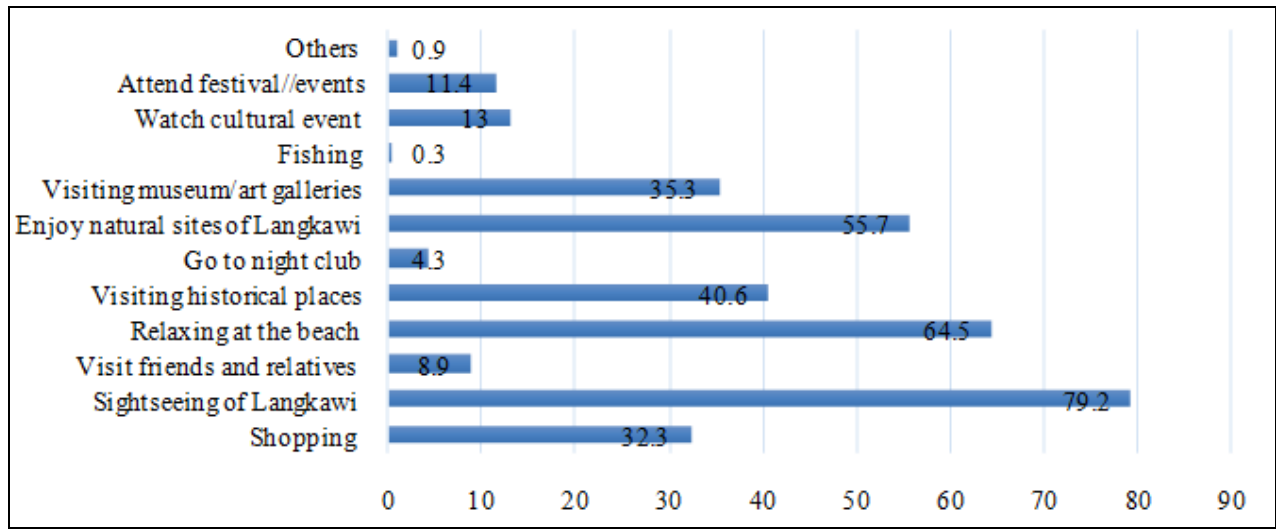

Figure 1. Tourist Purposes of Visiting Langkawi Island

\section{Tourists' Perceptions of Langkawi}

The findings as depicted in Figure 2 highlight 22 items on tourists' perceptions of Langkawi as the world tourism destination. Majority of the tourists want to experience travelling in Langkawi as much as possible (96.9\%). This is followed by they are interested to travel to Langkawi (96.8\%). Further, there are a variety of food and drinks in Langkawi which they can enjoy (93.9\%). Most tourists also perceive Langkawi as worth visiting $(90.4 \%)$ and most of them are satisfied with their visits to Langkawi (89.2\%). Additionally, the findings significantly show that tourists really enjoyed their trips in Langkawi. Most tourists would recommend Langkawi to others as a tourist destination $(88.7 \%)$.

More, tourists also agree that Langkawi is a popular tourist destination (87.8\%) and a unique tourist destination (86.1\%). Most tourists perceive buying a vacation in Langkawi as buying a gift for themselves (86.4\%). They also consider vacation in Langkawi as pleasurable for them $(86.0 \%)$ and interest them a lot $(82.4 \%)$. Further, majority of the tourist also perceive Langkawi as a de stination that they would revisit in the future $(83.3 \%)$. The findings of the survey also show that tourists attach ed great importance of visiting Langkawi (79.2\%). They perceive Langkawi as providing quality service through the accommodation sector (73.8\%) and also agree that the transportation sector in Langkawi is comfortable (73.4\%).

Question on the arrangement made for the trip in Langkawi shows that tourists would encourage travelling to Langkawi using tour package $(70.1 \%)$. Interestingly, most tourist would visit Langkawi regardless of the high visitation cost $(65.8 \%)$. Hence, the findings are probably consistent where the tourists have mixed emotion regarding Langkawi (54.3\%). Some of the tourists have broad knowledge of travelling to Langkawi $(51.8 \%)$ and in fact some of them perceive the cost of travelling to Langkawi is high compared to other regions $(42.4 \%)$. Only few tourists have second thought about visiting Langkawi in the future $(25.9 \%)$ and find that it is complicated to choose Langkawi as tourist destination $(25.5 \%)$.

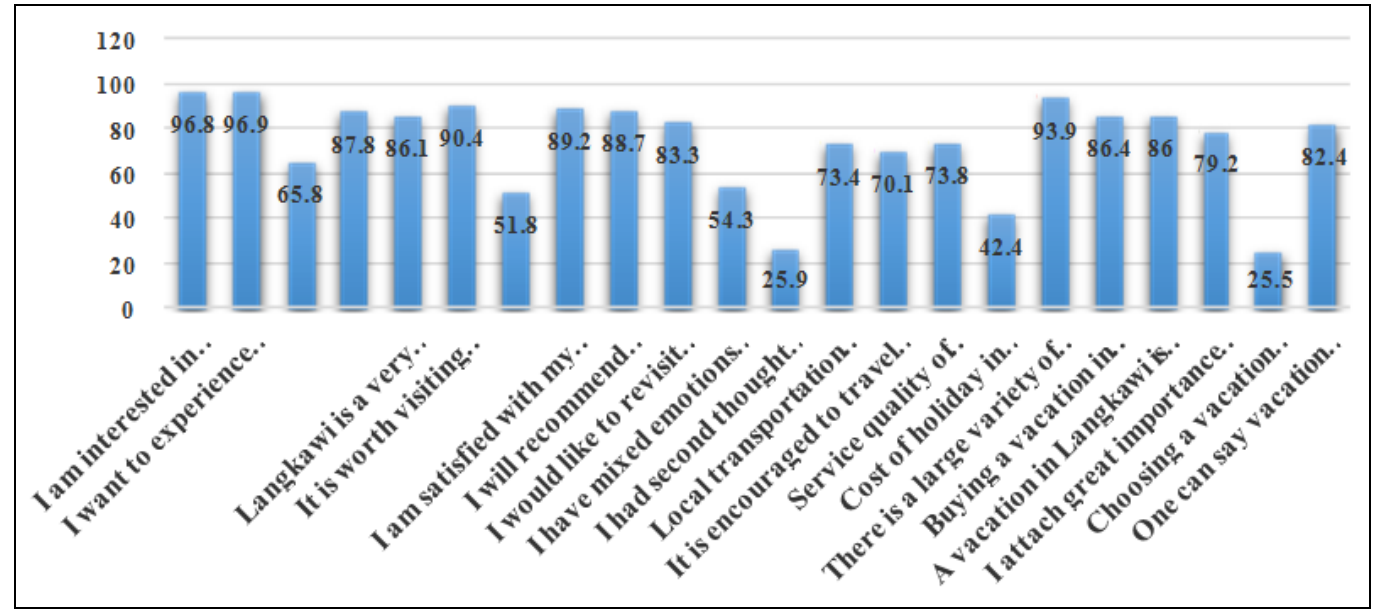

Figure 2. Tourists' Perceptions of Langkawi Island as a World Tourism Destination

Additionally, the tourists were also asked to name the value of promoting Langkawi Island as a world tourism destination (Table 2). They believed that Langkawi Island can be internationally promoted based on the values it possessed. The majority of tourist found Langkawi as a natural island destination (84.8\%). It is a fact that looking at Langkawi Island brochure today, the island is being promoted as natural tourist destination. Further, they also believed Langkawi Island is a welcoming destination to the tourist (62.5\%), followed by traditional tourist destination $(43.0 \%)$.

Besides these values, the tourists also found that Langkawi Island is an authentic destination (39.4\%) and a historical destination (33.4\%). The findings moreover indicated that Langkawi can be promoted as an ecotourism destination (31.5\%) and because it also has a value of fresh destination (30.1\%). Additionally, the tourists believed Langkawi Island can be valued as nostalgic (21.0\%) and invigorating destination $(19.8 \%)$. Few of the tourists valued Langkawi Island as contemporary destination (10.3\%), luxury destination $(4.3 \%)$ and stylish destination $(2.5 \%)$. 
Regarding the portrait of Langkawi Island as a world tourism destination, the survey revealed interesting findings. As depicted in Figure 3, the majority of tourist potrayed Langkawi Island as a destination which tourists aim to visit (70.6\%).

Most of them also potrayed Langkawi Island as destination with various places to visit $(70.3 \%)$ and a destination visited by couples (48.7\%). Some of the tourists described Langkawi Island as a destination that makes people happy (48.2\%). Further, some of them also pictured Langkawi Island as a destination for the whole family $(47.6 \%)$.

Table 2. Tourists' Perceptions regarding the Value of Langkawi Island as a WorldTourism Destination

\begin{tabular}{|l|c|}
\hline \multicolumn{1}{|c|}{ Profiles } & Percent \\
\hline Natural island destination & 84.8 \\
\hline A welcoming destination to tourist & 62.5 \\
\hline A traditional tourist destination & 43.0 \\
\hline An authentic destination & 39.4 \\
\hline Historical destination & 33.4 \\
\hline An ecotourism destination & 31.5 \\
\hline A value of fresh destination & 30.1 \\
\hline Nostalgic destination & 21.0 \\
\hline Invigorating destination & 19.8 \\
\hline Contemporary destination & 10.3 \\
\hline Luxury destination & 4.3 \\
\hline A stylish destination & 2.5 \\
\hline
\end{tabular}

This is followed by destination which offers good value for money (44.6\%) and a safe destination to visit (32.8\%). Additionally, few of the tourists' potrayed Langkawi Island as an easy detination to get to $(28.8 \%)$ with various range of quality accommodation $(23.8 \%)$ and it was also potrayed by the tourists as a year round destination (19.6\%). Finally, only few of the tourists indicated Langkawi Island as expensive destination $(7.8 \%)$ and a destination for older people $(3.7 \%)$.

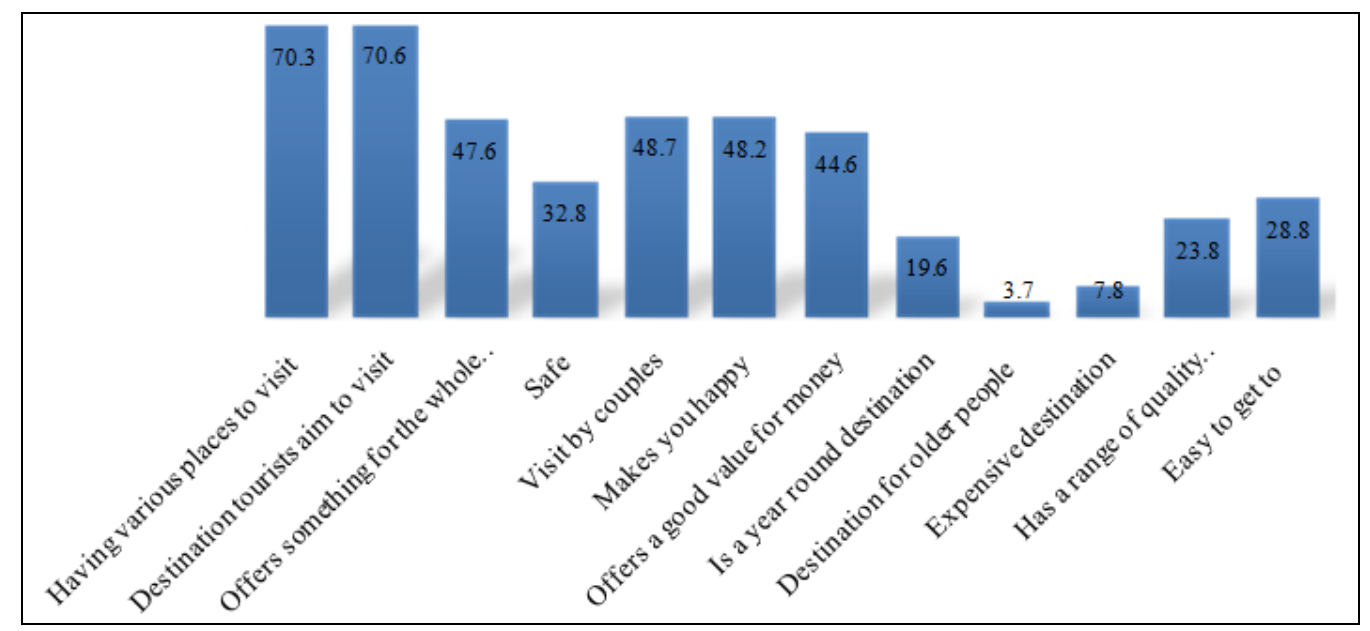

Figure 3. Tourists' Perceptions regarding the Potrait of Langkawi Island as a World Tourism Destination

\section{DISCUSSION}

Based on the findings, it is highlighted that most tourists have visited Langkawi Island to experience the natural resources and historical places of the island. This is in line with previous study by Nair and Azmi (2008) where they noted that the main purpose for tourists visiting Langkawi Island is to have a simple relaxing holiday. Additionally, the study is also consistent to other studies regarding tourists motive to visit tourism destination (Ndlovu, 2015; Pantouvakis and Patsiouras, 2016). This is also probably due to the fact that Langkawi Island has been promoted as a unique island full of myths and legends. Shopping is not counted as vital purpose and activity by the tourists who visited Langkawi Island even though it is a free-duty destination.

As for promoting Langkawi Island as a world tourism destination, the findings indicate that Langkawi Island has so many values and can be promoted as tourism destination throughout the world as it objective to be in the top 10 world tourist destination map. The study is similar to the findings by Ezeuduji et al. (2016) regarding tourists experience and satisfaction of Cape Town where the researchers found that among tourists valuable experience are memorable visit, valuable visit, friendly and hospitable population, level of service quality at facilities in the city, being one of the best places and destination's good value for money.

However, it is also noted that Langkawi Island received only a small number of tourists from Indonesia and Thailand. This could be the fact that the neighbouring countries probably visited other destinations with different cultural values or perhaps visiting their own countries. This could be due to the fact that Indonesia and Thailand also have their own beautiful island which is known through out the world as tourism island destinations such as Bali in Indonesia and Phuket in Thailand.

The findings of the study eventually would assist the stakeholders of the tourism industry in Langkawi Island particularly the policy makers and tourism planners to have better information regarding the profiles, purposes and perceptions of tourists visiting Langkawi Island. Additionally it would assist LADA to highlight and conserve natural resources in Langkawi Island and at the same time sustain the destination with its myths and legends. The information moreover can also be used by the marketing planners to effectively promote Langkawi Island as world tourism destination. Knowing tourists purposes and perceptions of Langkawi Island probably would assist the travel agencies to plan better promotional strategy.

The findings may also provide marketing researchers and planners with some valuable view of the choice of appropriate markets based on the values and portrait of the destination. This probably could differentiate the tourists' perceptions of Langkawi Island and also meet the 
tourist's future demand. Further, the marketing sector can use the promotional activities through the internet and other electronic media including to be utilized to attract the new and existing tourists to Langkawi Island.

\section{Limitations}

The study, however, is only focused on tourists visiting the island. It has not taken into account the stakeholders' awareness such as the policy makers, community and tourism marketers. Evidently, there is limited research statistics and/or information available on tourists' demographic profiles to compare with the current findings. It is suggested that future research could include more number of tourists and more extensive research to gain further insight into profiling tourists visiting Langkawi Island.

\section{Acknowledgements}

This study is sponsored by Universiti Utara Malaysia under the University Grant Scheme, S/O Code 13700.

\section{REFERENCES}

Ahmed, Z.U. (1991). The influence of the components of a state's tourist image on product positioning strategy. Tourism Management, 12(4), 331-340. https://doi.org/10.1016/0261-5177(91)90045-U

Anand, S., \& Sen, A. (2000). Human development and economic sustainability. World Development, 28(12), 2029-2049. https://doi.org/10.1016/S0305$750 \mathrm{X}(00) 00071-1$

Assael, H. (1984). Consumer behavior and marketing action, Kent Pub, Co.

Athula Gnanapala, W.K. (2015). Tourists' perception and satisfaction: implications for destination management. American Journal of Marketing Research, 1(1), 7-19.

Augustyn, M., \& Ho, S.K. (1998). Service quality and tourism. Journal of Travel Research, 37, 71-75. https://doi.org/10.1177\%2F004728759803700110

Baloglu, S., \& McCleary, K. (1999). A model of destination image formation. Annals of Tourism Research, 26(4), 868-897. http://dx.doi.org/10.1016/S01607383(99)00030-4

Bertan, S., \& Altintaș, V. (2013). Visitor perception of a tourism destination: the case of Pamukalle. Tourismos, 8(1), 115-132.

Breitsohl, J., \& Garrod, B. (2016). Assessing tourists' cognitive, emotional and behavioural reactions to an unethical destination incident. Tourism Management, 54, 209-220. https://doi.org/10.1016/j.tourman.2015.11.004

Chheang, V. (2011). Angkor heritage tourism and tourist perceptions, Tourismos, 6(2), 213-240.

Ezeuduji, I.O., November, K.L., \& Haupt, C. (2016). Tourist profile and destination brand perception: the case of Cape Town, South Africa. Economica, 12(4), 115-132.

Farsani, N.T., Esfahani, M.A.G., \& Shokrizadeh, M. (2019). Understanding tourists' satisfaction and motivation regarding mining geotours (case study: Isfahan, Iran). Geoheritage, 11(3), 681-688. https://doi.org/10.1007/s12371-018-0318-8

Heung, V.C.S., \& Quf, H. (2000). Hong Kong as a travel destination: an analysis of japanese tourists' satisfaction levels, and the likelihood of them recommending Hong Kong to others. Journal of Travel and Tourism Marketing, 9( 1-2), 57-80. https://doi.org/10.1300/J073v09n01_04

Law, E. (1995). Tourist destination management: issues, analysis and policies. New York: Routledge.

Maghsoodi Tilaki, M.J., Hedayati-Marzbali, M., Abdullah, A., \& Mohsenzadeh, M. (2017). Towards tourism development: bridging the gap between tourists' expectations and satisfaction. Geojournal of tourism and geosites, 1(19), 104-111.

Munien, S., Gumede, A., Gounden, R., Bob U., Gounden, D., Perry, N.S. (2019). Profile of visitors to coastal and marine touri sm locations in Cape Town, South Africa. GeoJournal of Tourism and Geosites, 27(4), 1134-1147. https://doi.org/10.30892/gtg.27402-421

Nair, V., \& Azmi, R. (2008). Perceptions of tourists on the responsible tourism concept in Langkawi, Malaysia: are we up to it? TEAM Journal of Hospitality and Tourism, 5(1), 27-44.

Ndlovu, J. (2015). Authenticity, emotion and experience: tourists' motivation for visiting re-enactment sites in Kwazulu-Natal. African Journal of Hospitality, Tourism and Leisure, 4(1), 1-12.

Pantano, E., Priporas, C., \& Stylos, N. (2017). 'You will like it!' using open data to predict tourists' response to a tourist attraction. Tourism Management, 60, 430-438. https://doi.org/10.1016/j.tourman.2016.12.020

Pantouvakis, A., \& Patsiouras, C. (2016). Tourists' selection criteria and motivation. Does nationality matter? SPOUDAI - Journal of Economics and Business, $66(1 / 2), 22-31$

Sekaran, U., \& Bougie, R. (2010). Research method for business: a skill building approach (5 $5^{\text {th }}$ edition). West Sussex, UK: John Wiley \& Sons Ltd.

Wang, C., Qu, H., \& Hsu, M. (2016). Toward an integrated model of tourist expectation formation and gender difference. Tourism Management, 54, 58-71. https://doi.org/10.1016/j.tourman.2015.10.009

Zikmund, W.G., Banin, B.J., Carr, J.C \& Griffin, M. (2010). Business research methods ( $8^{\text {th }}$ edition) USA: South-Western Publishing Company.

*** Langkawi Development Authority LADA (2015). Statistics of tourist arrival in Langkawi in 2012. www.lada.gov.my/Langkawi/statistic.htm.

*** Langkawi Development Authority LADA (2016). Statistics of tourist arrival in Langkawi in 2015. www.lada.gov.my/Langkawi/statistic.htm

*** Langkawi Development Authority LADA (2019). Statistics of tourist arrival in Langkawi in 2018. www.lada.gov.my/Langkawi/statistic.htm

*** Tourism Malaysia (2016). Tourism Malaysia: Media Centre. http://www.tourism.gov.my/corp/media/default.asp. 